\title{
Konstruksi Media Terhadap Perempuan Terlibat Kasus Korupsi dalam Tayangan Televisi
}

Oleh

\author{
Hadiati Erry, Irwan Abdullah, Wening Udasmoro ${ }^{1}$
}

\begin{abstract}
Abstrak
Artikel ini memfokuskan pada konstruksi media-televisi terhadap perempuan yang terlibat kasus tindak pidana korupsi. Dalam sepuluh tahun terakhir fenomena perempuan masuk dunia politik pemerintahan semakin meningkat, tetapi sekaligus juga diikuti oleh semakin banyaknya perempuan yang terjerat perkara korupsi. Pertanyaan pokok yang ingin dijawab dalam penelitian ini adalah bagaimana media massa mengkonstruksi perempuan terlibat korupsi melalui produksi dan reproduksi wacana yang dilakukan lewat ekspose pemberitaannya. Studi ini menggunakan metode analisis wacana kritis dari Norman Faircloug. Konstruksi media terhadap perempuan terlibat korupsi lebih banyak dibelokan ke isu irotis, domistik, dan suka glamour, bukan pada substansi masalah korupsi itu sendiri. Proses domestikasi oleh media ini mengindikasikan bahwa di ranah politik masih merupakan ranah laki-laki. Konteks sosial budaya akan fenomena tersebut merujuk bahwa dalam masyarakat ternyata masih patriarkis, sehingga jika ada perempuan aktivis politik mengalami kasus politik, media pun kemudian mengkonstruksi perempuan tidak beranjak dari sektor domistik. Produksi wacana seperti itu terus-menerus dilakukan televisi, terlebih lagi ketika mengambil momentum perempuan yang terkena kasus tindak pidana korupsi. Implikasi lebih lanjut, televisi semakin menegaskan dan meneguhkan bahwa ranah politik bukanlah ranah perempuan, melainan laki-laki.
\end{abstract}

Kata kunci: Konstruksi media, perempuan, korupsi dan tayangan televisi

\begin{abstract}
This article focuses on the construction on women who involved in corruption made by television. In the last ten years, there are increasing phenomenon on the women participation in politic but on the other side it also means the increasing amount of woman who involved in corruption. The main question in this research is how the mass media constructs the image of women who involved in corruption through the production and reproduction of discourse on the news that they produces. This study uses critical discourse by Fairclough. The media constructions on women who involved in corruption are more exposing on the issue of eroticism, domestic and glamorous lifestyle, rather than the substance of the corruption problem itself. Process of domestication shows that politic still become dominated by men's rules. The social cultural contexts also refer to the patriarchal system, so the media construction on women who involved in corruption is still in the domestic framework. The productions of domestic discourses are reproduced by television, especially using the moment of corruption case that involved women. The impact then television legitimizes that politic is the dominant field of men than women.
\end{abstract}

Keywords: media construction, women, corruption, and television show

\footnotetext{
${ }^{1}$ Hadiati Erry adalah kandidat Doktor Program Studi Kajian Budaya dan Media. UGM, mempunyai minat pada kajian kritis perempuan dan media. Irwan Abdullah, Guru Besar Antropologi Fakultas Ilmu Budaya UGM. Wening Udasmoro Dosen Fakultas Ilmu Budaya UGM.
} 
Jurnal Pemikiran Sosiologi Volume 2 No. 2, 2013

Konstruksi Media Terhadap Perempuan Terlibat Kasus Korupsi Dalam Tayangan Televisi

Hadiati Erry, Irwan Abdullah, Wening Udasmoro

\section{A. Pendahuluan}

Sejak berakhirnya rezim pemerintahan Orde Baru 1998, terdapat perubahan signifikan dalam dinamika politik di Indonesia. Alih ubah sistem politik dari otoritarian ke transisi demokrasi membuka iklim baru dalam berbagai entitas kehidupan politik, ekonomi, dan sosial budaya. Iklim serba komando, tiba-tiba berubah menjadi serba tersebar yang diikuti oleh menguatnya masyarakat sipil dalam menentukan arah kebijakan pemerintah. Peran elite politik sipil yang sebelumnya tidak lebih sebagai ornamen, tiba-tiba mendapat ruang politik yang begitu bebas dalam mengeskpresikan kepentingannya. Bersamaan dengan itu militer secara gradual mulai menarik diri dari kehidupan politik pemerintahan, dan berkonsentrasi pada upaya membangun profesionalisme.

Menguatnya politik sipil, semakin dalam masuk ke ranah kekuasaan negara melalui jalur Pemilu yang demokratis. Pada awalnya, ketika Pemilu 1999, politik sipil berangkat dengan penuh idealisme untuk membangun sistem pemerintahan yang transparan, akuntabel, dan partisipatoris atau bertekat mewujudkan good governance. Kekuatan politik sipilpun kemudian lebih mendominasi dalam pengambilan keputusan, yang ditandai oleh semakin besarnya kewenangan lembaga legislatif. Terjadi pergeseran signifikan dalam pembagian kekuasaan politik pemerintahan yang cenderung ke arah legislatif.

Sebagai upaya mewujudkan lembaga legislatif yang demokratis, sejak bergulirnya reformasi membuka akses bagi perempuan untuk terjun ke dunia politik pemerintahan. Proporsi perempuan yang masuk parlemenpun kemudian bertambah signifikan setelah disetujui melalui undang-undang kepartaian. Eksistensi perempuan dalam kehidupan politik di Indonesia juga sudah diperjuangkan dalam Undang-Undang (UU) Nomor 10 Tahun 2008 Tentang Pemilu DPR, DPD, DPRD, yang menyatakan setiap partai politik wajib menyertakan minimal 30 persen perempuan setiap bakal calegnya. Hal tersebut membawa angin segar bagi bangsa ini, utamanya kaum perempuan. Pasalnya, sebagai sebuah negara yang kehidupan politiknya sedang berkembang, tak jarang kesadaran untuk menerima dan memperjuangkan hak atas kebebasan kaum minor (perempuan) kerap diabaikan dalam kehidupan bermasyarakat, berbangsa dan bernegara di negeri ini. Maksud dan tujuan pemerintah dengan dibukanya kran bagi perempuan untuk berkiprah dalam dunia politik sebagaimana yang ditegaskan dalam UU tersebut tentu saja adalah untuk memberikan pemahaman dan kesadaran bagi masyarakat bahwa perempuan bukan lagi makhluk nomor dua sebagaimana yang selalu dipersepsikan masyarakat Indonesia pada umumnya selama ini. Karena selama ini hampir dalam segala aspek kehidupan, kaum perempuan selalu dikonotasikan sebagai kaum penurut, penghibur dan pelengkap. Tendensi dalam konteks interaksi sosial, budaya dan politik yang dibangun nyaris selalu melemahkan posisi perempuan.

Salah satu motivasi utama dibukanya kesempatan bagi perempuan terjun dalam dunia politik kepartaian dan pemerintahan, disamping sebagai manifestasi amanat demokrasi, juga mempunyai tujuan praktis, antara lain mendorong pemerintahan yang bersih dan transparan. Berkembang asumsi bahwa perempuan lebih berpotensi menjalankan politik yang bersih 
Jurnal Pemikiran Sosiologi Volume 2 No. 2, 2013

Konstruksi Media Terhadap Perempuan Terlibat Kasus Korupsi Dalam Tayangan Televisi

Hadiati Erry, Irwan Abdullah, Wening Udasmoro

daripada laki-laki, karena dalam praktik politik sebelumnya jarang perempuan terlibat dalam korupsi. Akan tetapi asumsi ini dalam perkembangan lebih lanjut gugur oleh fakta politik itu sendiri. Seiring dengan maraknya praktik korupsi di jajaran politisi sipil, baik di lembaga legislatif maupun eksekutif, dalam sepuluh tahun terakhir ini tidak sedikit perempuan yang terlibat dalam tindak pidana korupsi.

Salah satu fenomena dalam kasus pemberantasan korupsi di Indonesia pada akhir tahun 2011 dan awal 2012 adalah disangkanya dan bahkan ditangkapnya beberapa perempuan sebagai pelaku korupsi. Beberapa perempuan tersebutdiantaranya adalah Malinda Dee, Angelina Sondakh, Miranda Gultom dan beberapa nama lain yang diberitakan sangat fenomenal dan sangat mengundang perhatian besar dan membuat banyak kalanganmenjadi terkejut karena sebagian besar mereka memandang korupsi sebagai tindakan maskulin. Kemudian yang terakhir ditetapkannya Gubernur Provinsi Banten, Ratu Atut Chosyiah sebagai tersangka oleh KPK dalam kasus tindak korupsi suap pada ketua MK dan pencucian uang.

Sementara itu, perubahan situasi politik yang cukup signifikan tersebut, juga menjadi titik balik bagi dunia media massa sebagai salah satu kekuatan pilar demokrasi. Meskipun kehadiran televisi swasta sudah ada sejak era Orde Baru, tetapi mengalami perubahan karakter ke arah yang lebih berdaya sebagai entitas politik baru terjadi sejak era reformasi. Terutama ketika lahir dua stasiun televisi swasta, yaitu TV One dan Metro TV, maka televisi semakin menentukan. Dengan kata lain, jika sebelumnya media massa praktis lebih banyak dikontrol oleh negara, tetapi sejak berakhirnya Orde
Baru atau yang populer disebut sebagai era reformasi, berbalik menjadi entitas politik yang cukup menentukan dalam dinamika politik di Indonesia kontemporer. Media massa, terutama televisi begitu intensif terlibar dalam proses pengambilan keputusan yang berkait dengan kehidupan publik. Televisi tampil begitu dominan dalam mengkonstruksirealitasmasyarakat dengan segala kepentingannya yang melekat sebagai korporasi bisnis.

Setiap kali muncul persoalan politik pemerintahan yang aktual, televisi senantiasa mengangkatnya ke permukaan sebagai tema diskusi publik. Tidak terkecuali ketika fenomena praktik korupsi semakin marak, maka televisi terlibat intensif dalam proses diskusi publik. Televisi terus memproduksi wacana di seputar praktik korupsi dengan mengaitkannya ke arah isu kuasa dan ideologi. Isu kekuasaan berhubungan dengan semakin terbukanya perempuan masuk ke politik pemerintahan, sementara isu ideologi berkaitan dengan praktik politik gender.

Menyusul semakin maraknya praktik korupsi, tidak terkuacuali yang dilakukan oleh politisi perempuan, televisi pun sering mengangkatnya ke publik melalui berbagai tayangannya. Sebagai kekuatan yang mampu mengkonstruksi realitas, televisi sering menyodorkan tayangan yang menampilkan perempuan korupsi melebar ke berbagai dimensi, yang sering kali tidak sensitif gender. Produk media yang dianggap tidak berkeadilan tersebut dihasilkan antara lain dipengaruhi oleh kekurangpahaman tentang gender atau bahkan mengabaikan kesetaraan gender, sehingga produk yang dihasilkan juga akan bias gender. Di sinilah terjadi titik temu antara pengelola media yang bias gender dan 
Jurnal Pemikiran Sosiologi Volume 2 No. 2, 2013

Konstruksi Media Terhadap Perempuan Terlibat Kasus Korupsi Dalam Tayangan Televisi

Hadiati Erry, Irwan Abdullah, Wening Udasmoro

kekuatan media dalam mengkonstruksi realitas. Hasilnya adalah khalayak akan semakin dimapankan pemahamannya tentang nilai-nilai atau ideologi bentukkan tersebut.

Tayangan berita tentang perempuan dan korupsi juga menjadi aspek-aspek yang kemudian sering dijual untuk mendapatkan atensi dari pemirsa sekaligus sebagai usaha meraup keuntungan bagi pembisnis. Banyak tayangan yang berkaitan dengan perempuan yang diberitakan secara tidak adil diantaranya mengungkap kehidupan privat mereka, sehingga membuka ruang bagi publik untuk andil dalam merespon dan menjustifikasi kasus-kasus tertentu termasuk kasus perempuan yang terlibat dalam kasus korupsi.

Tayangan tentang korupsi di televisi secara progresif memiliki implikasi luas dalam hubungannya dengan imaji laki-laki dan perempuan yang terekam secara tidak sadar oleh masyarakat. Oleh karena itu, untuk mencermati fenomena kontroversi mengenai kesetaraan gender di media masa, maka studi dari perspektif media dan budaya mengenai tayangan berita perempuan di televisi khususnya tentang isu perempuan yang terlibat kasus korupsi menjadi penting, mendesak dan relevan dilakukan untuk mengungkap bagaimana diskursus perempuan dan korupsi di televisi dalam menayangkan berita tersebut. Secara lebih spesifik, penelitian ini ingin menjawab pertanyaanpertanyaan bagaimana perempuan yang terlibat kasus korupsi direpresentasikan di media televisi? Wacana apa saja yang dihadirkan dalam tayangan pemberitaan perempuan yang terlibat kasus korupsi pada media televisi? Stereotipe apa saja yang dimunculkan dalam tayangan berita perempuan yang terlibat kasus korupsi di media televisi?
Kepentingan apa yang mendasari pemberitaan tersebut? Serta ideologi apa yang ingin dibentuk?

\section{Korupsi, Gender, dan Media Massa}

Korupsi memiliki banyak pengertian, sosiolog korupsi Syeh Hussein Alatas (1986:61) menyebutkan benang merah yang mendasari aktivitas korupsi, yaitu subordinasi kepentingan umum di bawah kepentingan dan tujuan-tujuan pribadi yang mencakup pelanggaran norma-norma, tugas dan kesejahteraan umum, dibarengi dengan kerahasian, pengkhianatan, penipuan dan ketidakpedulian yang luar biasa akan akibat yang diderita oleh masyarakat. Definisi lain dari korupsi yang paling banyak dirujuk, termasuk oleh World Bank dan UNDP, adalah "the abuse of public office for private gain". Dalam arti yang lebih luas, definisi korupsi adalah penyalahgunaan kekuasaan publik untuk kepentingan pribadi atau privat yang merugikan publik dengan cara-cara bertentangan dengan ketentuan hukum yang berlaku. Sedangkan UU No. 31 Tahun 1999 jo UU No.20 tahun 2001 Pasal 2, merumuskan korupsi sebagai: (1) perbuatan melawan hukum; (2) dengan maksud memperkaya diri sendiri atau orang lain; dan (3) 'dapat' merugikan keuangan atau perekonomian negara. 'Secara melawan hukum' artinya suatu perbuatan dapat dipidana, jika ada aturannya dalam Undangundang (hukum formil), atau tidak sesuai dengan rasa keadilan atau norma kehidupan masyarakat (hukum materiil). Kata 'dapat' merugikan keuangan atau perekonomian negara artinya: tindak pidana korupsi dianggap ada tidak hanya ketika kerugian negara telah terjadi, tapi juga ketika unsur-unsur perbuatan korupsi telah terpenuhi. 
Jurnal Pemikiran Sosiologi Volume 2 No. 2, 2013

Konstruksi Media Terhadap Perempuan Terlibat Kasus Korupsi Dalam Tayangan Televisi

Hadiati Erry, Irwan Abdullah, Wening Udasmoro

Persoalan korupsi apabila dikaitkan dengan isu gender juga mengundang perhatian kalangan pemikir dan aktivis perempuan. Kalangan pemikiran feminisme ekologis misalnya menganggap bahwa laki-laki lebih korup daripada perempuan. Alasannya, perempuan memiliki sifat mendidik, merawat dan memelihara. Sifat ini, yang tercermin terutama dalam fungsi reproduksi, perempuan dianggap tidak pantas melakukan korupsi. Pandangan ini memperoleh bukti di mana negaranegara dengan tingkat keterwakilan perempuan yang tinggi dalam politik ternyata tingkat korupsinya rendah. Sebaliknya negara-negara dengan keterwakilan perempuan rendah tingkat korupsinya tinggi. Penelitian lain menunjukkan bahwa perusahaan yang dimiliki laki-laki cenderung lebih suka menyuap dibandingkan dengan perusahaan yang dimiliki dan dikelola perempuan. Hal yang sama, negara yang memiliki banyak politisi dan manajer perempuan cenderung lebih rendah korupsinya (Dollar et.al.. 2011:112).

Korupsi bisa terjadi dimana saja dan dilakukan siapa saja baik laki-laki maupun perempuan artinya tidak mengenal gender. Konsep gender dinilai bisa membantu menguak tabir persoalan eksistensial manusia yang dalam kurun waktu yang panjang dan turun temurun telah menyebabkan subordinasi, represi, dominasi dan hegemoni terhadap suatu jenis kelamin-perempuan (Ibrahim, 1998: 29). Konsep gender juga dapat menyadarkan perempuan bahwa selama ini mereka dalam posisi marginal dan telah didiskriminasi secara sistematis melalui berbagai mekanisme yang terdapat dalam masyarakat maupun sistem negara.
Dalam pandangan kritis, media juga dipandang sebagai wujud dari pertarungan ideologi antar kelompok-kelompok yang ada dalam masyarakat. Dalam hal ini, media bukan merupakan sarana yang netral yang menampilkan kekuatan dan kelompok dalam masyarakat secara apa adanya, melainkan kelompok dan ideologi yang dominan itulah yang akan tampil dalam pemberitaan. Pada posisi Jurnalis terlihat perbedan yang jelas dari dua pendekatan ini dalam hal bagaimana posisi dan peran jurnalis dalam menjalankan perannya. Bagi jurnalis yang berperspektif gender maka mereka tidak hanya bertindak sebagai jurnalis semata tapi juga berperan sebagai aktivis dengan ideologinya yang memperjuangkan keadilan dan kesetaraan gender. Tapi perlu digarisbawahi bahwa aktivis disini diimbangi dengan sikap profesionalisme sebagai kontrol untuk menjaga kualitas dari pemberitaan atau tulisannya.

Dalam pandangan pluralis, wacana jurnalistik seharusnya adalah wacana yang straight, langsung, tanpa opini dan penafsiran wartawan, sehingga fungsi wacana sebagai pengantar realitas terwujud. Sebaliknya, pandangan kritis memiliki konsepsi yang berbeda dalam memandang wacana. Menurut pandangan kritis, wacana selalu mengedepankan kelompok dominan dan menggusur kelompok marginal yang dalam penelitian ini adalah perempuan, khususnya terdakwa kasus korupsi. Oleh karena itu dalam pendekatan jurnalisme berperspektif gender, wacana merupakan alat untuk menghasilkan liputan yang sensitif gender dan berpihak pada perempuan sebagai kelompok marginal. 
Jurnal Pemikiran Sosiologi Volume 2 No. 2, 2013

Konstruksi Media Terhadap Perempuan Terlibat Kasus Korupsi Dalam Tayangan Televisi

Hadiati Erry, Irwan Abdullah, Wening Udasmoro

\section{Gender dan Televisi}

Pemahaman atas konsep gender sebenarnya merupakan isu mendasar dalam rangka membahas masalah hubungan antara kaum perempuan dan laki-laki, atau masalah hubungan kemanusiaan. Persoalan lain, kata gender merupakan kata dan konsep asing, sehingga usaha menguraikan konsep gender dalam konteks Indonesia sangatlah rumit untuk dilakukan (Fakih, 1996, hlm. 5-6).

Untuk memahami konsep gender itu sendiri, terlebih dahulu hendaklah melakukan pembedaan akan kata gender dan seks (jenis kelamin). Pengertian jenis kelamin itu sendiri merupakan pembagian antara jenis kelamin laki-laki dan perempuan melalui sifat biologis yang dimiliki manusia, sedangkan gender itu sendiri merupakan suatu sifat yang melekat pada kaum laki-laki maupun perempuan, dimana sifat-sifat tersebut dikonstruksi secara sosial maupun kultural oleh berbagai media, sehingga dapat dikenal dan dikonsumsi oleh khalayak. Misalnya bahwa perempuan itu dikenal lembut, cantik, emosional, atau keibuan, sementara laki-laki dianggap kuat, rasional, perkasa, dan jantan. Ciri dari sifat tersebut merupakan sifat-sifat yang dapat dipertukarkan, dimana ada pula laki-laki yang jantan, emosional, lembut, maupun perkasa, begitupula dengan perempuan ada yang kuat, rasional, perkasa dan sebagainya. Semua hal yang dapat dipertukarkan antara sifat laki-laki dan perempuan, yang bisa berubah dari waktu ke waktu serta berbeda dari tempat ke tempat lainnya, maupun berbeda dari suatu kelas ke kelas yang lain, itulah yang dikenal dengan konsep gender (Fakih,1996: 9).
Televisi memiliki posisi yang berbeda, keunggulan pada kandungan gambar gerak dan suara sekaligus memposisikan televisi, setidaknya hingga hari ini, sebagai pemangku peran penting dalam penyebaran arus informasi kepada khalayak. Dengan pengemasan tayangan yang menyasar segala kalangan, baik tua, muda, pria, perempuan, anakanak, menjadikan televisi sebagai media yang paling strategis dalam menyerap penonton. Televisi selalu menyuguhkan sajian bagaimana perempuan seharusnya. Perempuan dikonstruksikan untuk hidup sesuai dengan kehendak dan penilaian masyarakat. Begitu seterusnya, dan inilah yang terjadi. Tubuh perempuan seolah dikendalikan oleh televisi dan bagaimana masyarakat laki-laki memandang dan mempersepsikannya. Sebagai akibatnya,perempuan akhirnya diposisikan menjadi orang yang tak percaya diri dan bahkan mengalami krisis kepercayaan.

Di antara berbagai perspektif feminisme yang ada, penelitian ini akan menggunakan perspektif feminis sosialis sebagai acuan dalam melakukan analisis terhadap fenomena yang diteliti. Hal ini disebabkan perspektif ini memberikan kerangka yang komprehensif pada adanya penindasan terhadap perempuan di media massa. Feminisme sosialis yang muncul dengan penekanan pada dikotomi publik-privat yang tergantung pada budaya patriarki dan yang mengarahkan pertimbanganpertimbangan kontekstual yang krusial pada kelas dan ras menawarkan potensi yang paling besar sebagai sebuah kerangka kerja yang komprehensif pada penindasan perempuan di media massa, khususnya televisi (Stevees dalam Creedon, 1993: 211). 
Jurnal Pemikiran Sosiologi Volume 2 No. 2, 2013

Konstruksi Media Terhadap Perempuan Terlibat Kasus Korupsi Dalam Tayangan Televisi

Hadiati Erry, Irwan Abdullah, Wening Udasmoro

Dalam kehidupan masyarakat sehari-hari, terdapat berbagai macam tayangan berita, yang secara sadar atau tidak, langsung maupun tidak langsung, disengaja atau tidak disengaja, melakukan atau menunjukkan diskriminasi gender. Hal tersebut banyak menimbulkan perasaan risau di benak masyarakat yang secara langsung maupun tidak langsung mengetahui efek atau dampak yang dapat ditimbulkan oleh fenomena tersebut, karena secara perlahan-lahan, kita (masyarakat) mulai belajar "melek huruf" tentang media. Kita (masyarakat) pun masuk pada budaya media massa (mass mediated culture), dimana salah satu media yang sangat populer dalam menyebarkan dan melestarikan ideologi gender adalah benda ajaib yang disebut sebagai televisi (Kris Budiman, 1999: 12-13). Melalui media massa yang semakin lama berkembang semakin cepat menjadi salah satu kunci penting dalam kaitannya penanaman ideologi gender yang ada di masyarakat maupun penyatuan pikiran (hegemoni) yang dilakukan pihak-pihak media massa dalam hal ini televisi dalam tayangan berita perempuan yang terlibat kasus korupsi yang bertujuan 'maximizing profit'. Penanaman ideologi tersebut seturut dengan pengertian ideologi menurut Althusser. Ideologi menurut Althusser, selalu berbasis material dan dalam masyarakat kapitalis kontemporer, ideologi akan selalu berjalan melalui apa yang disebut sebagai 'aparat ideologi': aparat agama, media massa politik, keluarga, hukum, sistem media massa politik, serikat dagang, komunikasi dan budaya. Kesadaran, menurut Althusser dikostruksi melalui ideologi, sehingga dalam hal ini ideologi adalah sistem pemaknaan yang akan membentuk setiap orang dalam hubungan imaginer pada hubungan nyata di kehidupan mereka (Macdonell: 1996:27).

\section{B. Metode Penelitian}

Penelitian ini menggunakan pendekatan kualitatif yang mencoba mengumpulkan sebanyak mungkin informasi, khususnya yang terkait dengan pertanyaan, "what is going on here?" Kualitatif-kritis tersebut memiliki ciri-ciri sebagai berikut (Connole, Smith, \& Wiseman, 1993: 87):

(1) berlatar alamiah,

(2) peneliti sebagai instrumen kunci,

(3) data yang dianalisis secara induktif dan hasilnya berbentuk deskripsi fenomena,

(4) dibangun dari asumsi-asumsi:

(i) ideologis secara terus terang,

(ii) kritis secara sosial,

(iii) politis pada hakikatnya dan,

(iv) pembebasan dalam orientasinya,

(5) bersumber dari paradigma ilmu sosial kritis dan,

(6) hasil penelitian diharapkan dapat memberikan pemahaman dan penyadaran kritis (critical awareness) kepada seluruh masyarakat baik laki-laki maupun perempuan tentang hakikat perempuan, terutama dari aspek ideologi yang akan selalu diperjuangkannya.

Data penelitian ini dalam bentuk tayangan berita perempuan yang terlibat korupsi di televisi, yang memiliki nilai ideologis tertentu serta relevan dengan penelitian ini. Tayangan berita perempuan yang terlibat dalam kasus korupsi di televisi. 
Jurnal Pemikiran Sosiologi Volume 2 No. 2, 2013

Konstruksi Media Terhadap Perempuan Terlibat Kasus Korupsi Dalam Tayangan Televisi

Hadiati Erry, Irwan Abdullah, Wening Udasmoro

Sedangkan perempuan yang terlibat dalam kasus korupsi yang dipilih antara: Miranda Swaray Goeltom, terdakwa kasus suap Bank Indonesia adalah guru besar Universitas Indonesia, Malinda Dee, terdakwa dalam kasus penggelapan dana nasabah Citibank adalah pejabat senior di Citibank dan Angelina Sondakh, terdakwa dalam kasus penggelapan dana Wisma Atlet adalah putri Indonesia yang juga anggota DPR RI.

Selanjutnya data dianalisis dengan menggunakan model analisis wacana kritis (Critical Wacana Analysis/CDA) yakni teknik analisis wacana kritis menurut Fairclough, dengan tahapan sebagai berikut (Fairclough, 1992: 92):

(1) analisis teks bahasa,

(2) analisis wacana praktis dan,

(3) analisis praktis sosiokultural.

\section{Pembahasan: Representasi Stereotipe di} Televisi

Media dalam merepresentasikan perempuan yang terkena kasus korupsi masih memandang secara stereotipe atau melakukan penetapan yang kurang sesuai dengan realitasnya. Terdapat asumsi yang berkembang bahwa kepercayaan dan gambaran umum atas suatu kelompok tersebut mempunyai perbedaan pengetahuan individu, karena stereotipe yang bisa didapat dari media, keluarga ataupun teman sebaya (Martin dan Nakayama, 2007: 189190). D.T. Campbell (1967: 821) memberikan petunjuk bahwa semakin besar perbedaan yang nyata tentang kebiasaan-kebiasaan tayangan berita perempuan yang terlibat kasus korupsi, segi penampilan fisik atau benda-benda kebudayaan, semakin besar kemungkinan hal-hal itu tampil pada gambaran stereotipe dari kelompok tayangan berita perempuan yang terlibat kasus korupsi.

Studi ini menemukan beberapa kasus, antara lain dalam kasus yang melibatkan Miranda Goeltom, yang ketika hadir di KPK menggunakan ikat pinggang kulit lebar bewarna hitam di luar baju tahanan KPK berwarna putih menjadi sorotan bagaimana selaku tahanan, dia masih tampil "modis". Bahkan berita bahwa Miranda Goeltom masih rutin merawat tubuhnya dengan melakukan pilates di dalam ruang tahanan pun bisa dijadikan berita. Perlakuan yang sama tidak ditemui pada laki-laki tidak ada media yang tertarik untuk menelisik dan memberiakan barang barang mewah apa saja yang dibelinya ketika dia bepergian ke luar negeri dengan menggunakan pesawat jet sewaan. Mungkin tidak ada yang peduli bagaimana cara dia berpakaian. Dengan melakukan penggambaran: 
Jurnal Pemikiran Sosiologi Volume 2 No. 2, 2013

Konstruksi Media Terhadap Perempuan Terlibat Kasus Korupsi Dalam Tayangan Televisi

Hadiati Erry, Irwan Abdullah, Wening Udasmoro

..."Malinda Dee perempuan penggila operasi dan Miranda Goeltom yang "genit berdandan"... (SCTV, 24 Juli 2012), maka media pada hakekatnya melakukan stereotyping atas perempuan. Hal tersebut tidak akan pernah diberitakan bila pelakunya laki-laki.

Sistem pemaknaan yang ada dalam budaya, bentuk kekerasan seperti itu dianggap sebagai hal yang sah. Ann Lyod dalam Jewkes (2005: 111) menegaskan bila perempuan melakukan kejahatan, respons yang lebih keras tertuju kepadanya dibanding bila yang melakukan kejahatan itu laki laki. Hal tersebut terjadi karena menurut Lyod, perempuan pelaku kejahatan dianggap gagal mematuhi sterotipe gender yang dilekatkan kepadanya. Perempuan harusnya bersikap merunduk dan tidak macam macam.

\section{Konstruksi Media Perempuan Korupsi}

Dalam media massa khususnya televisi tubuh perempuan justru menjadi alat persuasif yang digunakan untuk menjual berbagai komoditi, seperti mobil, minuman, barang-barang olah raga, dalam usaha memberikan daya tarik erotik pada suatu produk. Daya tarik erotik menjadi faktor perangsang yang cukup kuat untuk membangkitkan minat orang terhadap suatu produk. Kenikmatan, kesegaran, keindahan, kenyamanan, kelincahan dari suatu produk yang merupakan sifat-sifat perempuan direproduksi oleh media massa khususnya televisi.

Para jurnalis cenderung memfokuskan perhatian mereka pada aspek privat perempuan sebagai objek berita. Sebaliknya, laki-laki mendapatkan stempel sebagai grup dengan produktivitas yang dinormalisir. Kehidupan pribadi perempuan lebih banyak menjadi konsumsi karena aspek intim mereka dianggap sebagai pleasure atau kesenangan. Pertama-tama, wujud fisik perempuan dengan modalitas mereka menyimbolkan nilai estetik dalam dunia hiburan.

Meskipun pada kenyatannya perempuan yang dalam hal ini para perempuan yang terlibat dalam kasus korupsi adalah orang-orang yang mempunyai peran di sektor publik, stereotip peran domistik mereka lebih cenderung ditonjolkan karena apresiasi kolektif yang masih terpancang kuat terhadap representasi ini. Padahal, sorotan terhadap kehidupan privat ini sebenarnya bersifat rentan karena apresiasi masyarakat akan bersifat subjektif dan emosional. Opini publik akan terarah ke sebuah model judgement yang bersifat negatif. Sementara itu, kehidupan publik yang dengan sendirinya lebih merepresentasi kreativitas mengantar masyarakat pemirsa pada pemahaman positif, kurang ditekankan oleh media televisi. Sebagaimana temuan studi ini, bahwa ternyata konstruksi media terhadap perempuan terlibat korupsi lebih banyak dibelokan ke isu irotis, domestik, dan suka glamour, bukan pada substansi masalah korupsi itu sendiri. Proses domestikasi oleh media ini mengindikasikan bahwa di ranah politik masih merupakan ranah laki-laki. Konteks sosial budaya akan fenomena tersebut merujuk pada masyarakat yang ternyata masih patriarkis, sehingga jika ada perempuan aktivis politik mengalami kasus politik, media pun kemudian mengkonstruksi perempuan tidak beranjak dari steriotipe ibu rumah tangga.

Itulah sebabnya, televisi ketika mengkonstruksi perempuan yang terkena kasus korupsi, ditonjolkan sisi melodramatiknya. Bahkan televisi 
Jurnal Pemikiran Sosiologi Volume 2 No. 2, 2013

Konstruksi Media Terhadap Perempuan Terlibat Kasus Korupsi Dalam Tayangan Televisi

Hadiati Erry, Irwan Abdullah, Wening Udasmoro

berita seperti TV One dan Metro TV pun, juga secara intensif mengeksploatasi kesan melodramatik itu, sehingga makin menjauh dari masalah substansi tentang korupsi yang berkaitan dengan kekuasaan politik. Ada ketidakrelaan jika perempuan masuk ke dunia politik yang dikonstruksikan sebagai dunia laki-laki.

Sebagai ilustrasi kasus tindak pidana korupsi dengan terdakwa Angelina Sondakh. Hampir semua televisi menayangkan Angelina bukan dari sisi politik, melainkan dari sisi Angelina sebagai perempuan mantan artis, cantik, seksi, dan ibu rumah tangga yang sedang mengasuh bayi. Hirukpikuk kasus Hambalang dengan salah satu tertuduh Angelina Sondakh, bukan lagi menjadi berita dengan bobot politik tinggi, tetapi beralih menjadi pemberitaan artis, erotis, dan penuh dengan visualisasi melodramatik. Angelina sering ditampilkan sebagai sosok yang rapuh, memelas, dan sering menangis. Bukan sebagai sosok perempuan tegar, sebagaimana politisi perempuan, seperti layaknya politisi. Demikian pula ketika televisi menampilkan sosok Atut Choisyah, yang berulangkali diperlihatkan wajahnya yang murung, tegang, dan habis menangis. Jauh dari gambaran sebagai perempuan politisi yang tegar dan percaya diri, seperti sosok Margaret Tacther si perempuan "besi" dari Inggris misalnya.

Konstruksi media tersebut berakar pada aspek sosial budaya di Indonesia, yang hingga sekarang masih menempatkan perempuan di sektor domestik, bukan sektor publik. Itulah sebabnya, RA Kartini, yang merupakan tokoh pemikir radikal, dan konseptor utama keindonesiaan, tidak pernah ditampilkan sebagai sosok politisi kelas tinggi yang sangat besar konstribusinya dalam mendirikan negara bangsa yang bernama Indonesia. Akan tetapi, hingga sekarang proses domistikasi RA Kartini terus berlangsung melalui lembaga-lembaga strategis, seperti lembaga keluarga, sekolahan, dan bahkan birokrasi negara. Akibatnya sosok Kartini yang terkonstruksi dan berada dalam pikiran bangsa Indonesia, tidak lebih sekadar ibu rumah tangga, dan ikon busana Jawa. Di setiap bulan April, sekolahsekolah memperingati Hari Kartini, hanya dengan lomba-lomba busana, atau penuh dengan nuansa gadis-gadis berkebaya.

Semua itu membawa implikasi terhadap berkembangnya persepsi bahwa di dunia politik perempuan tidak lebih sekadar peran sekunder, perkecualian, dan bahkan sering ditampilkan sebagai penggoda tindak korupsi. Televisi semakin menegaskan peran domestik perempuan, dan semakin meneguhkan persepsi bahwa perempuan tidak mampu berpolitik, apalagi membangun good governance. Produksi wacana seperti itu terusmenerus dilakukan televisi, terlebih lagi ketika mengambil momentum perempuan yang terkena kasus tindak pidana korupsi. Implikasi lebih lanjut, televisi semakin menegaskan dan meneguhkan bahwa ranah politik bukanlah ranah perempuan, tetapi sangat lanang, dunia laki-laki, dan male area.

Konstruksi media terhadap perempuan yang terkena kasus korupsi juga tidak berpotensi sebagai agen, melainkan sebagai individu yang tertundukkan oleh struktur. Jika mengikuti tradisi pemikiran sosiologi strukturalistik, struktur merupakan entitas yang keberadaannya di luar individu atau merupakan faktor eksternal dan memiliki daya paksa terhadap tindakan inidividu. Struktur itu misalnya mewujud pada birokrasi pemerintah, agama, atau juga dalam konteks 
Jurnal Pemikiran Sosiologi Volume 2 No. 2, 2013

Konstruksi Media Terhadap Perempuan Terlibat Kasus Korupsi Dalam Tayangan Televisi

Hadiati Erry, Irwan Abdullah, Wening Udasmoro

tertentu adalah laki-laki yang merupakan teks yang mengendalikan. Beberapa perempuan berpandangan akan keterikatannya kepada struktur-struktur seperti keluarga, lingkungan, masyarakat, bangsa, agama, dan negaranya. Frasafrasa seperti "sebagai orang beriman", "sebagai seorang isteri", "sebagai seorang ibu", "sebagai warga bangsa Indonesia" dan "sebagai perempuan" sering muncul dalam teks-teks yang dihasilkan oleh perempuan itu.

Dalam konstruksi televisi, perempuan adalah makhluk yang menyandarkan pada kekuatan struktur yang lain yang lebih fundamental, yakni agama yang mengikat setiap makhluk-termasuk perempuan yang memeluk agama Islam. Dalam pandangan tersebut, apa yang dihadapinya adalah semata-mata karena kekuasaan struktur itu, tidak ada tempat untuk melawan struktur yang determinatif itu. Keadaan sejalan pandangan yang terkenal dari Julia Kristeva, seorang feminis pascastrukturalisme, yang mengatakan bahwa identitas sejumlah perempuan "sungguh-sungguh terbelah" akibat keharusan mereka menampilkan tindakan yang "seimbang" antara "komitmen profesional" dan "tanggung jawab terhadap keluarga". Selain ia harus sukses dalam peran profesionalnya, ia dituntut juga sebagai makhluk yang terikat dan tidak boleh mengabaikan atau meninggalkan keluarganya, pada masyarakatnya, dan pada bangsanya.

Hampir semua perempuan yang terlibat kasus korupsi, senantiasa terungkap oleh televisi sebagai perempuan yang lemah terhadap struktur. Bahkan Miranda Gultom yang terkenal sebagai perempuan penuh percaya diri, tetapi ketika di televisi ditampilkan sebagai perempuan yang kurang memiliki otonomi relatif terhadap struktur agama atau pun keluarga. Ia tampak seperti perempuan fatalistik dan pasrah terhadap semua yang terjadi. Televisi sama sekali tidak menampilkannya sebagai sosok yang penuh bertanggung jawab terhadap kasusnya yang sedang mengandung tindak pidana korupsi. Padahal kapasitas sebagai Diputi Senior BI, ia terkenal sebagai sosok perempuan yang mampu mengendalikan, mengontrol, dan otonom. Sebagai individu ia merupakan perempuan yang potensial dalam ranah publik, dan sering tampil sebagai pengambil keputusan. Akan tetapi ketika terlibat kasus korupsi, Miranda oleh televisi lebih banyak ditampilkan sebagai perempuan yang jauh dari kesan perempuan yang tangguh dan siap menghadapi pengadilan Tipikor.

Selanjutnya, oleh televisi, perempuan yang terlibat korupsi dikonstruksikan sebagai perempuan yang dependen terhadap keluarga. Tampak bahwa perempuan adalah makhluk yang menyandarkan pada kekuatan struktur yang lain, yakni "keluarga" yang mengikat perempuan yang memiliki tugas dan peran yang harus dilakukannya tanpa ada pertanyaan yang menggugat tugas dan peran itu. Tugasnya sebagai "ibu" telah membawanya kepada sebuah keadaan yang tidak mungkin diabaikannya. Ia sadar bahwa peran "sebagai seorang ibu" telah membawa konsekuensi tayangan berita perempuan yang terlibat kasus korupsi hingga apa yang dilakukannya perlu dinaturalisasikan dan dilembagakan kepada publik atau orang lain. “....Insya Allah saya butuh doanya semoga cepat selesai," kata Malinda ketika menuju ruang tahanan. Sementara ketika ditanya kabar, anak dan suami dia hanya menjawab singkat. "Alhamdulilah baik,...." kata dia (Antv : 04/04/2011). 
Jurnal Pemikiran Sosiologi Volume 2 No. 2, 2013

Konstruksi Media Terhadap Perempuan Terlibat Kasus Korupsi Dalam Tayangan Televisi

Hadiati Erry, Irwan Abdullah, Wening Udasmoro

Begitulah, televisi dalam mengkonstruksi terhadap perempuan yang terlibat kasus tindak pidana korupsi, tetap diposisikan sebagai lemah, gagap di sektor publik, dan tidak berdaya terhadap struktur seperti struktur keluarga dan agama. Fenomena itu mengindikasikan bahwa televisi sebagai lembaga penyiaran tetap masih merupakan korporasi yang bersifat lanang atau male industry.

\section{Penutup}

Media massa khususnya televisi, dalam membahas naturalisasi kekerasan sistemik terhadap perempuan melalui tayangan-tayangan berita perempuan yang terlibat korupsi di televisi, terungkap memiliki daya untuk merepresentasikan kekerasan terhadap perempuan, baik kekerasan yang ditujukan kepada fisik, psikologis, maupun simbolik. Implikasinya, tayangan-tayangan itu sangat berpotensi memapankan peran gender yang asimetris antara laki-laki dan perempuan. Dalam tayangan-tayangan berita perempuan yang terlibat korupsi terungkap ada relasi yang tidak seimbang antara laki-laki dan perempuan yang terlibat korupsi. Ideologi patriarkis maupun kapitalis terekam dalam relasi gender tayangan-tayangan berita perempuan yang terlibat korupsi tersebut. Pemosisian perempuan di ruang domestik dan pria di kancah publik pun dilakukan disini. Karakteristik tersebut meliputi ekspektasi pada sifat-sifat personal tertentu (perempuan mengasuh dan tergantung, pria asertif dan mandiri), peran-peran sosial (pria sebagai ayah dan pencari nafkah keluarga, perempuan sebagai istri dan ibu), dan pekerjaan-pekerjaan atau posisi-posisi sosial (pria menjadi tentara dan politisi, perempuan menjadi jururawat dan relawan).

Terungkap dalam hasil kajian ini bahwa tubuh perempuan dikonstruksi dalam berita yang di tayangkan di televisi tentang korupsi masih mengukuhkan ideologi patriarki dan kapitalisme. Dengan demikian dapat dikatakan bahwa dibalik konstruksi bentuk tubuh perempuan, terungkap media televisi berkiblat pada ideologi kapitalis yang terlihat melalui tayangan beritanya selalu mengutamakan genre yang profit oriented dan 
Jurnal Pemikiran Sosiologi Volume 2 No. 2, 2013

Konstruksi Media Terhadap Perempuan Terlibat Kasus Korupsi Dalam Tayangan Televisi

Hadiati Erry, Irwan Abdullah, Wening Udasmoro

konstruksi sosial didasarkan penilaian laki-laki dan keinginan dunia industri yang terkait dengan tubuh perempuan untuk kepentingan rating dan bisnis yang terus mengeruk keuntungan dengan konstruksinya. Kondisi tersebut menegaskan bahwa televisi dalam mengkonstruksi perempuan yang terlibat kasus tindak pidana korupsi, tetap diposisikan lemah, gagap di sektor publik, dan tidak berdaya terhadap struktur seperti struktur keluarga dan agama. Fenomena itu mengindikasikan bahwa televisi sebagai lembaga penyiaran tetap masih merupakan korporasi yang bersifat lanang (baca: laki-laki) atau male industry.

\section{Daftar Pustaka}

Abdullah,Irwan. 2001. Seks, Gender \& Reproduksi Kekuasaan. Yogyakarta: Tarawang

Abdullah,Irwan. 2006. Konstruksi dan Reproduksi Kebudayaan. Yogyakarta: Pustaka Pelajar

Agger, Ben. 2003. Teori Sosial Kritis: Kritik, Penerapan dan Implikasinya (terjemahan). Yogyakarta : Kreasi Wacana

Amir. P, Yasraf. 1998. Perempuan dan Media. Bandung: PT Remaja Rosdakarya.

Amir. P, Yasraf. 2003. Tafsir Cultural Studies Atas Matinya Makna. Yogyakarta: Jalasutra.

Budiman, Kris. 1999. Feminografi. Yogyakarta: Pustaka Pelajar.

Calhoun, Craig , Edward LiPuma \& Moishe Postone. 1993. Bourdieu: Critical Perspectives. Chicago : The University of Chicago Press.

Creswell, John W. 1994. Research Design, Qualitative \& Quantitative Approaches. Thousand OaksLondon-New Delhi : Sage Publications.

Foucault, Michel. 1997. Seks dan Kekuasaan : Sejarah Seksualitas, terjemahan. Jakarta Gramedia

Leiss, William et al. 1986. Social Communication in Advertising. USA: Methuen

Mc Fall, Liz. 2004. Advertising: A Cultural Economy. Thousand Oaks London-New Delhi : Sage Publications

Mooij, Marieke de. 1998. Global Marketing and Advertising: Understanding Cultural Paradoxes. London : Sage Publications.

Synnott, Anthony. 1993. The Body Social : Symbolism, Self and Society. London-New York : Routledge.

Vande Berg, L.R., Wenner, L.A., \& Gronbeck, B. E. .1998. Critical Approaches to Television. Boston: Houghton Mifflin Company. 
Jurnal Pemikiran Sosiologi Volume 2 No. 2, 2013

Konstruksi Media Terhadap Perempuan Terlibat Kasus Korupsi Dalam Tayangan Televisi

Hadiati Erry, Irwan Abdullah, Wening Udasmoro

Williamson, Yudith. 1978, Decoding Advertisement;

Ideology and Meaning in Advertising.

London: Marion Boyars.

Williams, Raymond. 2000. "Advertising: The Magic System" dalam Simon During (ed). The Cultural Studies Reader. London \& New York : Routledge

Wolf, Naomi. 2002. The Beauty Myth: How Images of Beauty are Used Against Women. New York: Perennial. 